\title{
F.D. Wesonga ${ }^{1}$ \\ S.W. Mukolwe ${ }^{1}$ \\ Fred Rurangirwa ${ }^{2}$ Cowdria ruminantium identified
in Amblyomma gemma
using a DNA probe pCS20
}

WESONGA (F.D.), MUKOLWE (S.W.), FRED RURANGIRWA. Identification de Cowdria ruminantium dans la tique Amblyomma gemina par une sonde ADN, pCS 20. Revue Élev. Méd. vét. Pays trop., 1993, 46, $(1-2): 179-181$

Des tiques de l'espèce Amblyomma gemma ont été récoltées sur des animaux sauvages dans un ranch de 10000 hectares, dans une région endémique pour la cowdrinse au Kenya, proche de Nairohi. A. variegatum est le vecteur principal de la cowdriose au Kenya. E.A. LEWIS a incriminé $A$. gemma comme vecteur de la cowdriose, dans un rapport publié en 1947, sans donner de détails. Des A.gemma adultes ont été récoltés sur girafe (Giraffa camelopardis), bubale (Alcephalus busephalus), antilope canna (Taurotragus oryx) et autruche (Struthio camelus). Les tiques non gorgées prélevées sur girafe ont été nourries sur 3 moutons Dorper sensibles, qui ont été examinés quotidiennement pour des signes cliniques de la cowdriose. Toutes les tiques, y compris celles nourries sur les moutons, ont été disséquées et les intestins ont été testés sur la présence de Cowdria ruminantium à l'aide d'une sonde ADN, la pCS20. Aucun des moutons sur lesquels les tiques ont été nourries n'a montré de symptômes de la cowdriose pendant les 60 jours d'observation après la fixation des tiques. La sonde ADN a identifié C.ruminantium dans les tiques prélevées sur antilope et girafe.

Mots clés: Antilope - Girafe - Ovin - Cowdriose - Cowdria ruminantium Isolement - Tique - Amblyomma gemma - Sonde ADN.

\section{INTRODUCTION}

Amblyomma gemma is the commonest species of Amblyomma on the Hopcraft ranch(4) located $20 \mathrm{~km}$ South East of Nairobi. This tick species has been reported to be capable of transmitting heartwater in the laboratory (15) and to be one of the vectors of heartwater in Kenya (6); however this was a single statement report and no details were given.

The main objective of the study was to establish if A. gemma is a vector of the disease on the ranch or if it simply acts as a reservoir of Cowdria ruminantium but playing little role in the actual transmission (of the disea-

1. Kenya Agricultural Research Institute, P.O. Box 274, Uthiru, Nairobi, Kenya.

2. Small Ruminant Collaborative Research Support program, Kabete, Kenya. se). NEITZ (9) reported that infection in Amblyomma species can survive in a single tick generation for over 3 years.

Two methods were used to determine if the ticks were infected : feeding the ticks on susceptible sheep and probing the midguts of the adult ticks using a cloned DNA probe, the pCS20.

Because of its sensitivity and the large number of samples involved, a cloned DNA probe is suitable for detecting Cowdria in tick vectors (14). C. ruminantium has been detected in A.variegatum (14) using a cloned DNA probe, pCS20 derived from a strain of the parasite isolated from Crystal Springs (Zimbabwe). This probe is recommended for the detection of $C$. ruminantium as it has a high level of specificity and sensitivity (compared to another clone, the pCS9 from the Kiswani strain of Kenya).

\section{MATERIALS AND METHODS}

The study was conducted over a 3 month period, late October to January. This is the period of the short rains and there is a relative increase in the number of most tick species (including $A$. gemma) on the ranch (12).

\section{Feeding of the ticks on sheep}

Adult $A$. gemma ticks were collected from 4 species of wildlife eland, giraffe, ostrich and hartebeest, during the weekly cropping exercises.

The unengorged ticks were attached to sheep within 24 hours of collecting them from the wild animals. Three Dorper sheep were used in the experiment. A total of 104 unengorged ticks, all from the giraffe (very few ticks were obtained from the other 3 wild animal species) were attached on the sheep with the help of earbags. The earbags were opened after 9-12 days. By this time, some of the female ticks were fully engorged and dropping off. The earbags were left on the sheep up to 70 days to allow the males to engorge and drop off.

During the entire period of tick feeding, the sheep were monitored by daily rectal temperature records and clinical inspection. 


\section{DNA separation from the mid-guts of A. gemma and probing for C. ruminantium}

The separation of the DNA material from the tick mid-guts and the subsequent DNA probing for $C$. ruminantium was done as described by WAGHELA et al. (14) the only difference being that the mid guts were pooled in groups or batches of 10 according to the animal species from which they were collected.The exception to this group size was for the ostrich and hartebeest where only 5 and 2 ticks respectively were collected.

\section{RESULTS}

\section{Feeding of the ticks on sheep}

None of the sheep on which (A. gemma) ticks were fed showed heartwater symptoms for up to 70 days after tick attachment. One of the sheep died of pneumonia 48 days after tick attachment. A brain crush smear was made and on observation there were no Cowdria colonies.

\section{Detection of C. ruminantium DNA in the ticks}

The pCS20 probe detected $C$, ruminantium in 2 out of the 3 tick batches collected from the giraffe and in the batch (one) from the eland. All the ticks from the ostrich and hartebeest were negative.

\section{DISCUSSION}

Whereas it is known that A. gemma can become infected and transmit $C$. ruminantium under laboratory conditions, the results of this experiment do indicate that there is indeed a good chance of this tick species acquiring the infection in an endemic area and subsequently transmitting the infection to susceptible livestock under natural conditions.

However, the efficiency of this tick species as vector compared to $A$. variegatum is not known. Further experiments need to be done to ascertain this.

There is little information on the host range of the immature stages of $A$. gemma: Since transmission of infection is transstadial, it is important from the epidemiological point of view to know the hosts on which these immature stages feed and thus acquire infection. The next phase of this study will focus on this. This will be useful in providing information regarding the control strategies to be adapted in cases of outbreaks especially in the non-endemic areas. A. gemma appears to play a bigger role in the epidemiology of heartwater in Kenya than it is thought.

\section{REFERENCES}

1. DU PLESSIS (J.L.). The electron microscopy of Cowdria ruminantium infected reticuloendothelial cells of the mammalian host. Onderstepoort $J$. Vet. Res:, 1975, $42: 1-11$.

2. FAO, 1975. Rescarch on tick-bornc cattle diseases and tick control, Kenya. Epizootiological survey on tick borne cattle diseases. Rome UNDP. Food and Agric. of the United Nations AG:DP/KEN/70/522 Technical Report.

3. GOFF (W.), BARBET (A.), STILLER (D.), PALMER (G.), KNOWLES (D.), KOCAN (K.), GORHAM (J.), McGUIRE (T.). Detection of Anaplasma marginale infected tick vectors by using a cloned DNA probe. Proc. Natl. Acad. Sci. USA, 1988, 85 : 919-923.

4. JONYO (J.). The influence of host species on the maintenance of ticks in the field by determining the relative'contribution of wild animals compared to domestic animals. 1988. (Unpublished).

5. KOCAN (K.M.), MORZARIA (S.P.), VOIGHT (W.P.), KIARE (J.), IRVIN (A.D.). Demonstration of colonies of $C$. ruminantium in the midgut epithelial cells of A. variegatum. Am. J. Vet. Res., 1987, 48 : 356-360.

6. LEWIS (E.A.). In : Annual report for 1947. Department of Veterinary Services, Kenya. Nairobi, Government Printer. p. 51.

7. MacKENZIE (P.K.I.), NORVAL (R.A.I.). The transmission of C. ruminantium by Amblyomma tholloni. Vet. Parasitol, 1980, $7: 265-266$.

8. MEBUS (C.A.), LEGAN (L.). Heartwater disease of domestic and wild ruminants. J. Am. Vet. Med., 1988, 192 : 949-952.

9. NEITZ (W.O.). Heartwater. Bull. Off. int. Epiz., 1968, 70 : 329-336.

10. NORVAL (R.A.I.), McKENZIE (P.K.I.). The transmission of Cowdria ruminantium by Amblyomma sparsum. Vet. Parasitol. , 1981, 8 : 189-191.

11. OBEREM (P.T.), BEZUIDENHOUT (T.D.). Heartwater in hosts other than domestic ruminants. Onderstepoort J. Vet. Res., 1987, 54 : 271-275.

12. ORINDA (G.). Tick dynamics on the Hopcraft Ranch. 1988. (Jnpublished report)

13. SHOMPOLE (S.), WAGHELA (S.D.), RURANGIRWA (F.R.), McGUIRE (T.C.). Cloned DNA probes identify Anaplasma ovis in goats and reveal a high prevalence of infection. J. Clin. Microbiol., 1989, 27 :2270-2735.

14. WAGHELA (S.D.), RURANGIRWA (F.R.), MAHAN (S.M.), YUNKER (C.E.), CRAWFORD (T.B.), BARBET (A.F.), BURRIDGE (M.J.), McGUIRE (T.C.). A cloned DNA probe identified Cowdria ruminantium in Amblyomma variegatum ticks. J. Clin. Microbiol., 1991, 29 : 2571-2577.

15. WALKER (J.B.), OLWAGE (A.). The tick vectors of C. ruminantium (Ixodoidea, Ixodidae, genus Amblyomma) and their distribution. Onderstepoort J. Vet. Res. , 1987, 54 : 353-379. 
WESONGA (F.D.), MUKOLWE (S.W.), FRED RURANGIRWA. Cowdria ruminantium identified in Amblyomma gemma using a DNA probe pCS20. Revue Élev. Méd. vét. Pays trop., 1993, 46, (1-2) : 179-181

Amblyomma gemma ticks were collected from wild animals on a 20,000 acre game ranch in a heartwater endemic area in Kenya, close to Nairobi. A. variegalum is the main vector of heartwater in Kenya. E.A. LEWIS, 1947, in a one sentence report has implicated A.gemma to be a vector of heartwater without giving any details. Adult $A$. gemma were collected from giraffe Giraffa camelopardalis, hartebeest Alcephalus busephalus, Eland Taurotragus oryx and ostrich Struthio camelus during cropping exercises. The unengorged ticks were fed on 3 susceptible Dorper sheep which were monitored daily for the clinical symptoms of heartwater. All the ticks, including those that were fed on sheep were dissected and the guts probed for the presence of Cowdria ruminantium using a cloned DNA probe, the pCS20. None of the sheep on which the ticks were fed showed heartwater symptoms up to 60 days from the attachment of the ticks. The DNA probe identified Cowdria ruminantium in the ticks collected from eland and giraffe.

Key words : Eland - Giraffe - Sheep - Heartwater - Cowdria ruminantium Isolation - Tick - Amblyomma gemma - DNA probe.
WESONGA (F.D.), MUKOLWE (S.W.), FRED RURANGIRWA. Identificación de Cowdria ruminantium en Amblyomma gemma mediante el uso de ADN probador pCS20. Revue Élev. Méd. vét. Pays trop., 1993, 46, $(1-2): 179-181$

Se recolectaron garrapatas de Amblyomma gemma en reses bravías, en un rancho de 10000 hectárcas, en una zona endémica para la cowdriosis en Kenia, cerca de Nairobi. A. variegatum es el principal vector de la cowdriosis en Kenia. En un reporte de 1947, E. A. LEWIS, menciona A. gemma como vector de la cowdriosis, pero no proporciona mayor detalle. Los adultos de $\boldsymbol{A}$. gemma se colectaron de jirafas (Giraffa camelopardalis), búbalos (Alcephalus busephalus), antílope (Tauratragus aryx) y avestruces (Struthio camelus) durante diversas prácticas de cultivo. Las garrapatas, no ingurgitadas, fueron alimentadas sobre tres ovejas Dorper susceptibles, en las cuáles se controlaron diariamente los síntomas clínicos de la cowdriosis. Todas las garrapatas, incluyendo aquellas alimentadas en ovejas, fueron disecadas y se examinaron los intestinos para la presencia de Cowdria ruminantium, mediante la utilización de clones probadores de ADN, el pCS20. Sesenta días después del inicio de la alimentación de las garrapatas, ninguna de las ovejas mostró síntomas de cowdriosis. El probador de ADN identificó Cowdria ruminantium en las garrapatas colectadas de antílopes y jirafas.

Palabras calves : Antílope - Jirafa - Ovino - Cowdriosis - Cowdria ruminantium - Aislanilento - Garrapata - Amblyomma gemma - Sonda de ADN. 